\title{
System of Evaluation of Intellectual Capital and Intangible Assets Created on the Basis of Intellectual Property
}

\author{
Niyaz M. Abdikeev \\ Institute of industrial policy and institutional development \\ Financial University under the Government of the Russian Federation \\ Moscow, Russia \\ Nabdikeev@fa.ru
}

\begin{abstract}
The article discusses the evaluation of the value of intellectual capital and intangible assets of the organization. Intellectual capital includes all the knowledge of the organization. These are different types of knowledge, innovations, know-how, knowledge possessed by the employees of the organization, the knowledge base of the organization, the electronic network and the database based on it, this cooperation with customers.All of that allows you to respond to changes in the market situation faster than competitors. That is, intellectual capital is a set of explicit and implicit knowledge. The main thing is that this is the knowledge that the organization can turn into profit. Intellectual capital is the result of the interaction of people with each other, people and information resources, as well as people and elements of physical capital in the production process. It is the result of past investments, but it is forward-looking. The assessment of intellectual capital is formed on the basis of the results of its future use.
\end{abstract}

Keywords: intellectual capital; intangible assets; intellectual property; valuation; innovation; new technologies.

\section{INTRODUCTION}

Intangible assets have a certain value for the company, although they have a different form of presentation than physical objects. Some of the intangible assets were recognized many years ago. These are patents, copyrights and trademarks.

Intangible assets include:

- market assets (service marks, product marks, trademarks, corporate name, business cooperation, licensing and franchise agreements, etc.);

- intellectual assets (patents, software, design rights, copyrights, trade secrets, know-how, trademarks);

- human assets (education, qualifications, skills and abilities of employees);

- infrastructure assets (corporate culture, management concepts and management processes, relationships, etc.).

The approaches to determining the cost of work on the creation of new technology, such as regulatory, adaptive, program-target and program, are considered. The method of calculating the value of intangible assets created on the basis of intellectual property and aimed at improving the technologies operating in the market, and the creation of fundamentally new products or fundamentally new technology. This method shows that the result of innovative projects can be used in determining the price of the contract for research and development. In this case, its main component is the expected result of the sale of the created intangible assets in the market. Thus, the method is a tool to stimulate performers to create market-promising results of research and development work.

\section{INTELLECTUAL CAPITAL AND INTANGIBLE ASSETS}

Intellectual capital (IC) includes all the knowledge of the organization. These can be ideas, different types of knowledge, innovations, know-how, knowledge owned by employees of the organization, the knowledge base of the organization, the electronic network and the database on its basis, this cooperation with customers. All of that allows you to respond to changes in the market situation faster than competitors. That is, intellectual capital is a set of explicit and implicit knowledge. The main thing is that this is the knowledge that the organization can turn into profit.

Intellectual capital is the result of the interaction of people with each other, people and information resources, as well as people and elements of physical capital in the production process. It is the result of past investments, but it is forwardlooking. The assessment of IC is formed on the basis of the results of its future use.

The intellectual capital, in L. Edvinson's interpretation [1], includes two components. The first is human capital, i.e. the totality of knowledge, practical skills and creative abilities. It is not the property of the company and is described in detail in the economic literature. The second is structural capital such as brands, documented business processes and everything that provides the performance of staff. The structural capital is the property of the company. It consists of consumer capital (relationship capital) and organizational capital.

Consumer capital is a set of established relationships with the entire environment of the company, primarily with customers. The organizational capital is the organizational knowledge, systematized and formalized competence of the company.

Their interpretation of IC suggested K. Sveiby [2]. He identifies the IC and intangible assets (IA). However, there are 
other interpretations of these concepts, since the question arises of their identity Are all intangible assets knowledge and able to benefit from their use? The balance sheet measures and sums the value of individual resources of the company, and the market considers and evaluates the company as a whole. Moreover, there is already a synergetic effect when the sum of the properties of the constituent parts is less than the properties of the system as a whole. Therefore, the cost of the whole must exceed the sum of the costs of its elements.

IA have a value for the company, although they have a different form of presentation than physical objects. Some of the IA was recognized many years ago. These are patents, copyrights and trademarks. However, only a few companies have tried to give a monetary evaluation of IA.

\section{IA include:}

- market assets (service marks, product marks, corporate name, business cooperation, licensing and franchise agreements, etc.);

- $\quad$ intellectual assets (patents, software, design rights, trade secrets, know-how, trademarks);

- human assets (education, qualifications, skills and abilities of employees);

- infrastructure assets (corporate culture, management concepts and management processes, relationships, etc.).

The scheme of the IC by K. Sveiby contains three elements: the competence of the employees (human capital), internal structure, external structure (customer capital, and relationship capital).

The competence of employees is the ability of people in the organization to act in different situations. It includes teaching, skill, education, experience, social skills, etc. The competence of employees creates internal and external structures.

The internal structure consists of goals, objectives, models, technologies, information systems, etc., which are owned by the organization. It includes business strategy and concept, process knowledge, patents and all information stored and implemented in computer systems. It provides the staff of the organization with the ongoing support they need to carry out their work.

The external structure consists of links with customers and suppliers, competitors, brands, reputation. An external structure is a relationship with suppliers, stakeholders, partners, and customers.

\section{METHODOLOGY OF THE RESEARCH}

\section{Approaches to valuation of intellectual capital}

If IC is put in a row with other factors of production, there is a problem of its estimation. Today, traditional methods of economic valuation and measurement, based on the principles of accounting, have ceased to be adequate to the conditions. For example, traditional accounting practices treat a trademark as an intangible asset that, by analogy with a tangible asset, loses its value in the course of its use and transfers its value in parts to a manufactured product. In this regard, IA are accounted for according to the same rules as tangible assets, depreciation rates are applied to them and their write-off is made. At the same time, the trademark or brand in the process of their exploitation not only does not lose its value, but, on the contrary, it is often increased. Moreover, many elements of intangible assets are not reflected in the balance sheets, including connections with consumers, staff qualifications, knowledge base, etc.

Such researchers of knowledge-based economic intellectual capital as L. Edvinsson [1], K. Sveiby [2], M. Malone [3], T. Stewart [4], E. Broking [5] and others have developed a number of methods to assess intellectual capital.

In particular, K. Sveiby identifies 26 methods of valuation and measurement of intellectual capital, grouped into four categories:

- methods of direct measurement of intellectual capital (Direct Intellectual Capital methods, DIC). It is based on the identification of intellectual capital and the valuation of the monetary values of individual assets or components of intellectual capital, after which the integrated assessment of the intellectual capital of the company;

- methods of market capitalization (Market Capitalization Methods, MCM), when calculated the difference between the market capitalization of the company and the equity of its shareholders. The obtained value is regarded as the value of its intellectual capital or intangible assets;

- methods of return on assets (Return on Assets Methods, ROA). The ratio of the average income of the company before taxes for a certain period to the material assets of the company (ROA of the company) is compared with the same indicator for the industry as a whole. To calculate the average additional income from intellectual capital, the resulting difference is multiplied by the tangible assets of the company. Then, by directly capitalizing or discounting the resulting cash flow, you can determine the value of the company's intellectual capital;

- scoring methods (Scorecard Methods, SC). Various components of IA or IC are identified; indicators and indices are generated and recorded in the form of scoring or as graphs. The use of SC-methods does not imply a monetary valuation of intellectual capital. These methods are similar to methods of diagnostic information system.

All known methods of IC assessment are divided into four categories listed. It should be noted the relative proximity of DIC and SC methods, as well as MCM and ROA methods. In the first two cases, the movement comes from the identification of individual components of IC, and in the remaining it is from the integral effect.

None of the methods meet all objectives of the evaluation, so the choice methodically capital depends on the task and situation, for example, to study the company is usually most suitable methods of scoring and methods of direct measurement of intellectual capital.

In order to extract value from intellectual capital, organizations need to manage information flows between different types of capital that make up intellectual capital. The purpose of management of the intellectual capital of the 
enterprise is to achieve the maximum result from its use while minimizing the cost of its development.

The problems of efficient use of IC and IA are usually left out of management activities, as in domestic enterprises are mainly solved only the problem of accounting for such assets. This is due, in particular, to the lack of development or absence of the methods to assess the effectiveness of the IC management system, as well as the effectiveness of its creation and use.

Evaluation of the effectiveness of the management system intellectual capital is the calculation of a set of indicators. This is because the process of intellectual capital management involves the implementation of a large number of functions, the quality of which is difficult to assess. In addition, such indicators can be used as benchmarks in the development of the company's strategy for the creation, acquisition and use of intellectual capital. Methodological problems of accounting, analysis, management and evaluation intellectual capital and intangible assets are also considered in the works of domestic researchers [6-12.

\section{Approaches to the valuation of intangible assets}

Intangible assets can bedivided into three main groups: intellectual property (IP), organizational expenses, and goodwill.

IP includes industrial property, rights to secrets (know-how) and copyright objects.

Industrial property includes inventions, utility models, industrial designs, trademarks and breeding achievements.

The objects of copyright include: computer programs, databases, topology of integrated circuits, scientific public lectures.

The organizational costs include fees for lawyers for drafting constituent documents, services for the registration of the company and others. Costs for re-registration of constituent documents, the production of new seals and stamps intangible assets are not included.

Goodwill appears in an enterprise only if it has made a purchase of another enterprise. Business reputation can be defined as the difference between the purchase price of the acquired enterprise and the value of the balance sheet of all its assets and liabilities.

The market value standard is not always applicable to IA, as market value is the most probable price at which an object can be disposed of in an open market in a competitive environment. But for some intangible assets, it is difficult to talk about the most probable price of the transaction, because the market of such objects is underdeveloped.

For the valuation of IA, the same approaches that are traditionally used for the evaluation of objects are mainly applicable: cost, revenue and comparative. However, with respect to IA, the use of these approaches has its own specificity in intellectual capital, since intangible assets are rather unusual object for evaluation.

Key in the evaluation of IA is often a profitable approach. It is based on the income that the owner of the valuation object (IA) expects to receive. When assessing IA under the income approach, a method is sought to allocate income related to the assessed IA in order to determine the value of IA using the conventional methods of income approach (capitalization or discounting) [13].

There are a number of approaches to determining the cost of work on their creation in the practical intellectual capital of program-target, planning and management of the development of new technologies. The most frequently used and well proven both in our country and abroad are normative, adaptive, program-target and program approaches [14].

The normative approach provides for the establishment of a certain standard to determine the cost of work in the creation of new technologies as a percentage of the total cost of research and development (R\&D). In fact, all leading foreign countries adhere to a normative approach in one form or another. The normative approach is quite simple to implement, but it has low accuracy and can only be used to estimate the amount of work on the development of new technologies.

The adaptive approach is based on determining the share of financing for the creation of new technologies in a specific promising direction from the total cost of $R \& D$, depending on the goals set out in the development strategy of the enterprise.

Compared with the normative approach, the adaptive approach will determine the necessary costs depending on the development strategy of the enterprise. However, its practical application requires more raw data.

The program-target approach provides for full-scale research and development overall set of directions contained in the list of promising technologies for the enterprise.

A programmatic approach to determining the value of new technology creation and development involves extending the financing of new technologies over a period of time, taking into account the overall dynamism of the intellectual capital of $R \& D$ financing.

However, the considered approaches do not take into account the emerging market price and technical characteristics of the intellectual capital of the new technical intellectual capital and technology and the relevant trends.

In this regard, a method of calculating the value of IA created on the basis of the IP and the price of the contract for their development is proposed.

\section{THE RESULTS OF RESEARCH}

Calculation of the value of intangible assets created based on the IP and aimed at improving the technologies operating in the market

To calculate the value of intangible assets on the basis of the IP used to improve the technical level of the product or process, the following procedure is used, which is a modification of the capitalization method of parametric indices [15].

The following stages are implemented within the calculation procedure:

1. On the basis of the set of technical characteristics, the intellectual capital of the best analogues and the original technology, it is formed a set of indicators $i$ in the form of the vector $P_{i, k 0}$, the state of the basic production technology of the 
considered sample technical intellectual capital, which is "ideal" at the moment.

2. The characteristics of analogs and original technology are compared with the characteristics of the "ideal" sample. Parametric index is calculated:

$$
S P_{i, k}=P_{i, k} / P_{i, k 0} .
$$

At the same time, each technology of analogues of the original technology is assigned the corresponding numbers $k=$ $1,2, \ldots, n$; the original technology has the number $+1) ; i$ is technical characteristics of the intellectual capital of the technical intellectual capital (no more than five main characteristics of intellectual capital are usually used in the practical intellectual capital of marketing and benchmarking), $n$ is the number of analogues in the market. Reference model, characterized by the best performance among the analogues on the market, is assigned the number $k_{0}$.

3. The sum of the parametric indices of analog technologies and original technology is calculated:

$$
\sum_{i} S_{P_{i}, w_{i},}
$$

where $w_{i}$ is weight coefficient $P_{i}$ of the technical indicator, adopted in practice, the intellectual capital of marketing.

4. The economic effect of the original technology in relation to each $k$ of $n$ analogues is determined:

$$
C_{i f, k}=\left(\frac{\sum_{i} S P_{i, n+1} w_{i}}{\sum_{i} S P_{i, k} w_{i}}-1\right),
$$

where $k=1,2, \ldots, n$.

The economic effect caused by differences in the technical level of products is manifested in the change in the price of analogs: the price increases if the coefficient of technical improvement meets the condition:

$$
C_{\text {eff } k}>0 \text { for } k=1,2, \ldots, n \text {. }
$$

5. Intellectual capital forms the number of $k_{\min }$, analog having the lowest price of $P_{k \min }$ in the market.

Then, the additional revenue from the sale of the product on the market will be

$$
\boldsymbol{A R}=\boldsymbol{N} \times \boldsymbol{P}_{k \min } \times\left(\frac{\sum_{i} S P_{i, n+1} w_{i}}{\sum_{i} S P_{i, k \min } w_{i}}-1\right),
$$

where $N$ is physical volume of production.

6. Additional net profit obtained by improving the technological level of products is equal to

$$
\left.A N P=N \times P_{k \min } \times\left(\frac{\sum_{i} S P_{i, n+1} w_{i}}{\sum_{i} S P_{i, k \min } w_{i}}-1\right)\right)_{\times r} \times(1-f),
$$

where $r$ is the profitability ratio, taken, for example, for hightech industries is equal to $0.2 ; f$ is tax rate.

7. In the distribution of additional profit between the licensee and the licensor, the ratio of the cost of exploration and technological development to the total cost, including additional development of technologies and production organization, is used (1:4:16) [15], which is determined by the licensee's cost factor $\left(k_{c l}\right)$.

If the licensee conducts both exploratory research and technology development, then

$$
k_{c l}=\frac{1+4}{1+4+16}=\frac{5}{21} \approx 0,24 .
$$

When conducting only exploratory research,

$$
k_{c l}=\frac{1}{21} \approx 0,05 \text {. }
$$

In the development of technology $k_{c l}=\frac{4}{21} \approx 0,20$.

8. The additional net profit from the implementation of the $m$-th sample of equipment, improved on the basis of the IP at the time tm, is described by the equation

$$
\begin{aligned}
& A N P\left(t_{m}\right)=N_{m \cdot \max } \times P_{k \cdot \min } \times\left(\frac{\sum_{i} S P_{i . n+1} w_{i}}{\sum_{i} S P_{i . k m i n} w_{i}}-\mathbf{1}\right) \times r_{m} \times(1 \\
& \left.-f_{m}\right) \times k_{c l m} \times \\
& \quad\left(1-\frac{\mathbf{4}}{T_{m}^{2}}\left(t_{m}-\frac{T_{m}}{\mathbf{2}}\right)^{\mathbf{2}}\right),
\end{aligned}
$$

where $N_{m \cdot \max }$ is maximum physical volume of production sold on the market; $P_{k \text { min }}$ is the price of the $m$-th sample of technical intellectual capital and the market;

$T_{m}$ is total life time of production of a particular kind;

$$
t_{m}=t_{m 0}+\Delta t_{m}
$$

where $t_{m 0}$ is the beginning of the commercialization of the $m$-th sample of technical intellectual capital in relation to the time of market entry pioneer model of the intellectual capital; $\Delta t_{m}$ is the time period of commercialization of the original technology, measured in years.

9. Commercialization of products is carried out within $\Delta t_{m}$ years, therefore, taking into account the discount determined by the formula

$$
E_{m}=R_{\text {inf } m}+R_{\text {risk. } m}+R_{\text {inf. } m} \times R_{\text {risk. } m},
$$

where $R_{\text {inf.m }}$ is the inflation index at the time of commercialization of the $m$-th sample; $R_{\text {risk. } m}$ is the risk index from the implementation of the $m$-th sample of the improved technical and intellectual capital, the ratio to calculate the additional net profit from the implementation of the $m$-th sample of the technical and intellectual capital received by the licensee (researcher, developed by the intellectual capital of the technology and a specialist in engineering and production organization), depending on the coefficient of $k_{\mathrm{cl} m}$, is described by the 


$$
\begin{aligned}
& \operatorname{ANP}\left(F_{m}\right)=\sum_{n}^{F_{m}} N_{m \cdot \max } \times P_{\cdot k \cdot \min } \times\left(\frac{\sum_{i} S P_{i, n+\mathbf{1}} w_{i}}{\sum_{i} S P_{i, k \min } w_{i}}-\mathbf{1}\right)_{\times \times} \\
& r_{m} \times\left(1-f_{m}\right) \times k_{c l m} \times\left(1-\frac{\mathbf{4}}{T_{m}^{\mathbf{2}}}\left(t_{m}-\frac{T_{m}}{\mathbf{2}}\right)^{\mathbf{2}}\right) \times\left(1+E_{m}\right)^{-n},
\end{aligned}
$$

where $t_{m}=t_{m 0}+\Delta t_{m} ; F_{m}=T_{m}-t_{0 m}$.

10. To determine the cost of creating a technology to improve the $m$-sample of technological product, we take into account the additional profit obtained through its commercialization in the ratio

$$
E_{m}=\operatorname{ANP}\left(F_{m}\right) \times\left(1+r_{m}\right)^{-1},
$$

where $r_{m}$ is profitability of scientific and technical activities.

Thus, the licensor at the conclusion of the contract for the development of technology and/or exploratory research of engineering works and the organization of production should provide for the payment to the licensee of an amount equal to the ANP $\left(F_{m}\right)$, in which the $E_{m}$ is the cost of carrying out the relevant work.

Calculation of the value of intangible assets created based on intellectual property and aimed at creating a fundamentally new product or a fundamentally new technology

In the case of production of fundamentally new products or new technologies the value of IA is determined by the ratio

$$
S_{m}=V_{m} \times N_{E} \times k_{c l m},
$$

where $V_{m}$ is the expected revenue from the $m$-sample technology intellectual capital sold on the market, created on the basis of IP; $N_{E}$ is the knowledge-intensive sector of the market, within which it is expected to sell fundamentally new products.

The value of the cost of work on the creation of technology in the $m$-sample at the profitability of $r_{m}$ is determined by the formula

$$
E_{m}=V_{m} \times N_{E} \times k_{c l m} \times(1+r)^{-1} .
$$

The licensee at the time $t_{m}$ from entering the market receives a profit, determined by the following ratio

$$
\begin{aligned}
& \operatorname{Pr}_{l}\left(t_{m}\right)=V_{m} \times r_{m} \times\left(1-f_{m}\right) \times k_{c l m} \times \\
& \left(1-\frac{\mathbf{4}}{T_{m}^{\mathbf{2}}}\left(t_{m}-\frac{T_{m}}{\mathbf{2}}\right)^{\mathbf{2}}\right)_{\times\left(1+E_{m}\right)^{-n} .}
\end{aligned}
$$

$E_{m}$ defined in point 9 of the procedure of calculating the value of IA.

\section{CONCLUSION}

The paper considers various methods of economic evaluation of intellectual capital and intangible assets:

- methods of direct measurement of IC (DIC);

- market capitalization methods (MCM);

- methods of return on Assets (ROA);

- scoring methods (SC).

It is shown that traditional methods based on the principles of accounting cannot take into account many elements of intellectual capital and IA, in particular the scale and level of quality of interaction with consumers, staff qualifications, knowledge base, etc.

Analysis of methods of valuation of IA (intellectual value, organizational expenses goodwill) showed that the standard approaches such as cost income and comparative meet with many difficulties, because the IA is a non-standard object for evaluation. These methods do not take into account the price and technical characteristics of the products formed in the market. In this regard, a fundamentally new method of valuation of intangible assets created on the basis of the IP, which are fundamentally new to the market, or improving products on the market. The use of this method orients the manufacturer to organize the production of competitive products for the market.

The method of intellectual capital appraisal formulated in the result of innovative projects. It can be used to determine the price of the R\&D contract. In this case, its main component is the expected result of the commercialization of the created intangible assets. Thus, the method of intellectual capital is a tool to stimulate the creation of the economically perspective $\mathrm{R} \& \mathrm{D}$ products.

In conclusion, it should be noted that the method of calculating the cost of IA, which is the result of innovative projects, presented in the article, can be used to determine the price of the contract for R\&D. In this case, its main component is the expected result of the implementation on the market of created IA. Thus, the method is a tool to stimulate performers to create market-promising results of research and economically perspective $\mathrm{R} \& \mathrm{D}$ products.

\section{REFERENCES}

[1] Эдвинссон, Л. Корпоративная долгота: Навигация в экономике, основанной на знания. М.: Инфра-M, 2005 [Edvinsson L. Corporate longitude. Navigation in the knowledge-based economy. Moscow: Infra-M, 2005].

[2] Sveiby K. E. The New Organizational Wealth: Managing and Measuring Knowledge Based Assets. San-Francisco: Berrett Koehler, $1997 . \quad$ URL: http://www.sveiby.com/articles/MeasureIntangibleAssets.html.

[3] Edvinsson L., Malone M. S. Intellectual Capital: Realizing your company's true value by finding its hidden brainpower. NY: Harper Business, 1997.

[4] Стюарт Т. Интеллектуальный капитал. Новый источник богатства организаций // Новая постиндустриальная волна на Западе. Антология. М.: Академия, 1999. С. 372 400. [Stuart T. Intellectual Capital. A new source of wealth of organizations // The new wave in the post-industrial West. Anthology. Moscow: Academia, 1999. Р. 372-400].

[5] Брукинг Э. Интеллектуальный капитал. СПб.: Питер, 2001 [Brooking E. Intellectual Capital. St Petersburg: Piter, 2001].

[6] Булыга Р.П. Методологические проблемы учета, анализа и аудита интеллектуального капитала. М.: Финансовая академия при Правительстве Российской Федерации, 2005. [Bulyga R.P. Methodological problems of accounting, analysis and audit of 
intellectual capital. Moscow: Finance Academy under the Government of the Russian Federation, 2005].

[7] Абдикеев Н.M. Управление интеллектуальным капиталом организации // Инновационное развитие России: Проблемы и решения / Под ред. М.А. Эскиндарова, С.Н, Сильвестрова. М., 2014. C. 603-634. [Abdikeev N. M. (2014) Managing intellectual capital of the organization // Innovative development of Russia: problems and solutions / Ed. by M. A. Eskindarov, S. N. Silvestrov. Moscow, 2014. P. 603-634].

[8] Абдикеев Н.М. Киселев А.Д. Управление знаниями корпорации и реинжиниринг бизнеса. М.: Инфра-М, 2011. [Abdikeev N. M., Kiselev A. D. Knowledge management of corporation and reengineering of business. Moscow: Infra-M, 2011].

[9] Федотова М.А., Дресвянникова В.А., Лосева О.В Интеллектуальный капитал организации: управление и оценка. М.: Финансовый университет при Правительстве Российской Федерации, 2014. [Fedotova M.A., Dresvyannikova V.A., Loseva O.V. et al. Intellectual Capital of the Organization: management and evaluation. Moscow: Financial University under the Government of the Russian Federation, 2014].

[10] Козырев А.Н., Макаров В.Л. Оценка стоимости нематериальных активов и интеллектуальной собственности. M.: Интерреклама, 2003. [Kozyrev A.N., Makarov V.L. Valuation of intangible assets and intellectual property. Moscow: Interreklama, 2003].

[11] Смирнов С.А. Оценка интеллектуальной собственности. М.: Финансы и статистика, 2002. [Smirnov S.A. Valuation of intellectual property. Moscow: Finance and statistics, 2002].

[12] Балакирева Н.М. Нематериальные активы: учет, аудит, анализ. М.: Эксмо, 2005. [Balakireva N. M. Intangible assets: accounting, auditing, analysis. Moscow: Eksmo, 2005].

[13] Белышева И.Г., Козлов Н.П. Нематериальные активы компании: классификация и учет // Акционерное общество: вопросы корпоративного управления. 2008. № 5. С. 34-37. [Belysheva I.G., Kozlov N.P. Intangible assets of company: cost evaluation // Joint-stock company: corporate society. 2008. N 5. P. 34-37].

[14] Леонов А.В., Смирнов С.С., Нованов Д.Г. Адаптивный подход к определению объемов ассигнований на развитие базовых и критических военных технологий // Вооружение и экономика 2012. № 5(21).C. 47-59. [Leonov A.V. Smirnov S.S., Hovanov D.G. Adaptive approach to determining the volume of appropriations for the development of basic and critical military technologies // Weaponry and economics. 2012. N 5 (21). P. 47-59].

[15] Завлин П.Н., Васильев А.В. Оценка эффективности инноваций. СПб.: Бизнеспресса, 1998. [Zavlin P.N., Vasiliev A.V. Assessment of efficiency of innovations. St Petersburg: Business press, 1998]. 